Bangladesh Journal of Bioethics 2013; 4(2):22-33

\title{
ISLAMIC PERCEPTIONS OF MEDICATION WITH SPECIAL REFERENCE TO ORDINARY AND EXTRAORDINARY MEANS OF MEDICAL TREATMENT
}

\author{
Mohammad Manzoor Malik \\ Assistant Professor \\ Department of General Studies, \\ Kulliyyah of Islamic Revealed Knowledge and Human Sciences \\ International Islamic University Malaysia \\ E-mail: philomalik@iium.edu.my / philomalik@gmail.com
}

\begin{abstract}
This study attempts an exposition of different perceptions of obligation to medical treatment that have emerged from the Islamic theological understanding and how they contribute to diversity of options and flexibility in clinical practice. Particularly, an attempt is made to formulate an Islamic perspective on ordinary and extraordinary means of medical treatment. This distinction is of practical significance in clinical practice, and its right understanding is also important to public funded healthcare authorities, guardians of the patients, health and life insurance institutions, and employers who provide health care coverage to their employees. Not only these parties, but also lawyers and justice administration functionaries such as public prosecutors and judges are in need of understanding this distinction to deal with relevant litigations. The distinction could be made regarding terminally ill patients and non-terminally ill patients separately. The essential factors that matter in making the distinction between ordinary and extraordinary means of treatment are: (1) patient capacity (2) expert advice, and (3) nature of medication. Regarding terminally ill patients, medical treatment can become extraordinary because of (1) patient capacity and (2) nature of medication. In both these case the deciding condition applies: the expert advice taken from a group of physicians. In regards to non- terminally ill patients, extraordinary medical treatment includes three cases: (1) treatment that is known to be useless and futile, (2) treatment that endangers the life or cause more harm than what it removes, and (3) useful treatment, but the patient is unable to bear the cost.
\end{abstract}

Key words: medication, bioethics, extraordinary medical treatment, medical ethics

INTRODUCTION: Deciding on medical treatment becomes sometimes complicated because of the quality of available medical treatment; multifaceted considerations related to the patients, their financial strength, and the nature of the diseases they suffer. Making an adequate distinction between ordinary and extraordinary means of medical treatment is one of such difficult times. The distinction is of high significance in clinical practice and its right understanding is also important to public funded healthcare authorities, guardians of the patients, health and life insurance institutions, and employers who provide health care coverage to their employees. Not only these parties, but also lawyers and justice administration functionaries such as public prosecutors and judges are in need of understanding this distinction in dealing with relevant litigations. Therefore, an Islamic stance on the issue is attempted in this paper. The underpinnings of this discourse are necessarily rooted in the ways Muslims perceive importance of medical treatment from the basic theological sources: the Quran and the Sunnah. The multiple perceptions of obligation to medical treatment allow flexibility in the clinical practice and, at the same time, help formulating an executable, applicable distinction of ordinary and extraordinary means of medical treatment.

In the subsequent sections, the researcher will attempt to explore the position of the Quran and the Sunnah on the subject of medication; different perceptions of medication that have emerged from these sources from the early times to the present; and, finally, how by deriving on the aforesaid sources and perceptions, formulating the distinction between ordinary and extraordinary means of medical treatment is possible. 
SOURCES AND APPLIED METHODS IN ISLAMIC ETHICO-JURISTIC STUDIES: In face of changing circumstances and advances in medical science, Muslims seek guidance (hidayah) from the Quran, which is foremost a book of guidance: “... guidance unto those who ward off (evil)". ${ }^{1}$ Along with the Quran, the Sunnah is the second source: "... Obey Allah and obey the messenger and those charged with authority among you. If you differ in anything among yourselves, refer it to Allah and his messenger..." Beside the Quran and the Sunnah, there are other additional sources such as ijma (consensus), qiyas (analogical deduction), istihsan (juristic preference), al-maslaha al-mursalah (public interest), istidlal (textual indication), urf (common practice), etc. However, different schools of Islamic jurisprudence do disagree on inclusion and exclusion of some of these sources or understand them differently in terms of their scope and referents; yet, without any disagreement, they are unanimous on accepting the first two sources. The common agreeable authorities among all sects and schools of Islam in their theologies and jurisprudences are the Quran and the Sunnah alone. Moreover, ijma (consensus) depends itself on the Quran and Sunnah and it includes certain unanimous resolutions whereas qiyas (analogical deduction) is not the source of Islamic law; it is rather the method. Therefore, the door of taking decisions by making intellectual effort (ijtihad) is always open for competent Muslim scholars by rethinking the Quran and the Sunnah, especially when new issues (nawazi) emerge that require resolution from Islamic perspective.

The ethical, juristic, and doctrinal guidance from these two sources has manifested in a bulk of classics of Islamic studies known to Muslims as turath. Islamic turath is itself sometimes diversified with dimensions diverging in conclusions and converging in one or other way to the primary sources of Islam i.e. the Quran and the Sunnah. The rest of the sources are based on ijtihad of different sects and schools of Muslims. Regarding the first source, the Quran, the important matter is understanding it by using sound approach and valid methods; whereas, the Sunnah requires both verification of the authenticity of the reports and comprehension of their contents. There is a meaningful difference between hadith and the Sunnah, though they are very often used interchangeably. The Sunnah is an established path or practice; whereas, hadith is everything that is reported on any subject from the prophet Muhammad, including his sayings, deeds, approvals, and descriptions of his personality. Some of the narrations are abrogated or specific to particular persons or contexts. The various hadith (prophetic narrations) on any subject have led to difference of opinion on various subjects. However, the main ideal pursuit is to find what could be called as the Sunnah, for the practical purposes; and the most important categories of the Sunnah are those which either proves obligation (wujub), or prohibition (hurmah). Very closely connected to this methodological discourse is the consideration that scholars give to the higher intentions of Shariah or maqasid al-Shariah. The higher intentions of Shariah are in fact conceptual parameters that present the very essence of the spirit of Islam regarding laws and ethics. There are specific objectives and aims which Islamic Shariah wants to safeguard. Imam alGhazali (d. 505/1111), Al-Izz bin Abdul Salam (d. 660/1262) in, al-Syatib (d. 790/1388), to mention a few leading scholars, have raised the question: what is the end, or the objective of Shariah? The essential maqasid are five: life, intellect, faith, lineage, and property. ${ }^{3}$

QURANIC APPROACH TO HEALTH CARE AND MEDICATION: The Quranic approach to health care and medical treatment is based on its clear statements or verses. A comprehensive study would show that the Quran touches the subject in five ways.

Firstly, the actual healer, according to the Quran, is Allah himself, though means (asbab) of medication are not prohibited. The Quran states: "Whatever of good reaches you is from Allah..." 4 and "If God touches thee with affliction, none can remove it, but he: ..." The Quran tells the story of Ibrahim, the prophet, in which he says, "... And when I was sick, he (Allah) was the one who healed me". ${ }^{6}$ The story of Ayyub, (Job), the prophet, provides evidence for both divine favor in healing and resorting to appropriate means in pursuing cure. ${ }^{7}$ 
Secondly, the Quran, as the word of Allah, has power of healing. The Quran states "O mankind: there has come to you a direction from your lord and a healing for the (disease) in your hearts ..." This verse would mean that diseases are not just physical ones, but they can be spiritual, mental, and psychological. The Quranic worldview and its teachings on ethics, self purification and behavior provide guidance that could be used in healing patients who suffer from many diseases that are non-physical; for example, anxiety, despair, hopelessness, rage, excessive anger, jealousy, negative thinking, and some forms of minor depression, etc. However, the Quran proclaims its healing power in general sense that includes both physical and non-physical disease as it states: "And we send down of the Quran that which is a healing and a mercy to those who believe" ${ }^{9}$ and "... say unto them (O Muhammad): For those who believe it is a guidance and a healing..." ${ }^{10}$ This could be well illustrated by the prophetic traditions (hadith) that speak of the healing power of the Quran in curing the physical ailments. For example, one of the companions of the prophet Mohammad healed a chief of a tribe, who was bitten by a snake or stung by a scorpion, by reciting Surat al-Fatihah, the first chapter of the Quran. ${ }^{11}$

Thirdly, the Quran considers substances of having healing power. The Quran clearly mentions honey: "...There comes forth from their bellies, a drink of varying colour wherein is healing for men..." 12 This verse shows that healing could be done by using proper substances.

Fourthly, the Quran sets forth guidance on maintaining health. According to Imam Ibn al-Qayyim, the basic principles of medicine are three: prevention, maintaining good health, and removing harmful substances from a person's body. And these principles are mentioned in the Quran. Regarding prevention, Allah allows a sick person to perform tayammum (the Islamic act of dry ablution using sand or dust, which may be performed in place of ritual washing ), so preventing the sick person from using water, which may harm him $^{13}$; regarding maintaining good health, a traveler and ill are allowed to break their fast during Ramadan, for protection of their health, otherwise fasting along with the difficulties of travel can weaken them and affect their health adversely ${ }^{14}$; and regarding removing harmful substances from a person's body, Allah allowed shaving a person's head in ihram (for Hajj or Umrah) for the removal of harmful things, an exception to the general prohibition of doing so ${ }^{15} .{ }^{16}$

Lastly, the Quran gives very high importance to sanctity of life and provides clear injunctions that are relevant to contemporary issues in bioethics such as euthanasia, abortion, persistent vegetative state (PVS), and physician-assisted suicide. These guidelines include: prohibition of killing, consenting to self-destruction, suicide, and collaborating on accomplishing prohibited acts. Regarding the prohibition of killing, the Quran prohibits unjustified killing: "And do not kill anyone whose killing Allah has forbidden, except for a just cause...." ${ }^{17}$ In addition, intentional killing of a human being is highly prohibited: "And whoever kills a believer intentionally, his recompense is hell to abide therein, and the wrath and the curse of Allah are upon him, and a great punishment is prepared for him". ${ }^{18}$ Similarly, self-killing is prohibited: "... And do not kill yourselves (nor kill one another). Surely, Allah is most merciful to you." ${ }^{19}$ Equally, the Quran prohibits helping and collaborating on conducting sinful acts: "And do not help each other in sin and aggression".

\section{PROPHETIC TRADITIONS (THE SUNNAH) ON HEALTH CARE AND MEDICATION: The}

Sunnah or Hadith deal with medication in three ways.

The first type of the prophetic traditions encourages and in a recommendable fashion suggests opting for medical treatment. For example, the prophet Muhammad said, "...seek medicine, for Allah has not created a disease except that he has created its cure...."21; "There is no disease that Allah has created, except that he also has created its treatment" ${ }^{22}$; "... So you seek medical treatment and do not seek it unlawful" ${ }^{23}$; "It is not God sent down a disease but also sent down the cure" ${ }^{24}$; and "Verily, Allah does not send down a disease but also the medicine. The drug was known to the person who can know it and not known by those who could not tell." ${ }^{25}$ In addition, there is, in many chapters in the canons of Hadith that are related to the Prophetic traditions on the subject of medicine, mention of many substances, fruits, and items praised for their medicinal 
effects and therefore recommended for healing. Among these various stuffs are Indian incense ${ }^{26}$; black cumin ${ }^{27}$; and Talbina (a meal made from barley flour, formed by adding milk and honey), ${ }^{28}$ etc. Regarding quarantine, when epidemics outbreak, the prophetic tradition states: "If you hear of an outbreak of plague in a land, do not enter it; but if the plague breaks out in a place while you are in it, do not leave that place." 29

The second type of traditions speaks about the tawakkul (reliance upon God). For example, "Whoever seeks treatment by cauterization, or with ruqyah (incantation) then he has absolved himself of tawakkul (reliance upon Allah). ${ }^{30}$ The Prophet also said that seventy thousand men of his Ummah (Muslims), who neither practice charm, not take omens, nor do they cauterize, but they repose their trust in their lord, would enter paradise without rendering account. ${ }^{31}$ However, as mentioned earlier, medication is allowed and encouraged and so is ruqyah (incantation) allowed and proven as stated in the prophetic traditions. To suffice, "The Prophet used to treat some of his wives by passing his right hand over the place of ailment and used to say, "O Allah, the lord of the people! Remove the trouble and heal the patient, for you are the healer. No healing is of any avail but yours; healing that will leave behind no ailment". ${ }^{32}$ Furthermore, medication is part of the destiny one will come across as Abu Khuzamah narrated: "I said, 'O Messenger of Allah, the ruqyah (divine remedies - Islamic supplication formula) that we use, the medicine we take and the prevention we seek, does all this change Allah's appointed destiny? He said, 'They are in fact a part of Allah's appointed destiny". ${ }^{33}$

The third type of traditions, on the other hand, allow abstaining from medication, as Aishah (may Allah be pleased with her) narrates about an incident before the demise of the prophet (peace and blessings of Allah be upon him). She states: "We put medicine in one side of his mouth, but he started waving us not to insert the medicine into his mouth. We said: he dislikes the medicine as a patient usually does. But when he came to his senses he said: did I not forbid you to put medicine (by force) in the side of my mouth...."34 Ata bin Abi Rabih narrates: Ibn Abbas said to me: "May I show you a woman of paradise? I said: Yes. He said: here is this dark-complexioned woman. She came to Allah's apostle (may peace be upon him) and said: I am suffering from falling sickness and I become naked; supplicate Allah for me, whereupon he (the Holy Prophet) said: Show endurance as you can do and there would be paradise for you and, if you desire, I supplicate Allah that he may cure you. She said: I am prepared to show endurance (but the unbearable trouble is) that I become naked, so supplicate Allah that he should not let me become naked, so he supplicated for her". ${ }^{35}$

The trends and approaches to medication in the first two sources of Islam provide a rich matrix to rethink and resolve the emerging issues in bioethics. Likewise, the potentiality of these trends in deriving less strict and more flexible orientations can lead to formulation of flexible juristic and ethical normative guidelines and codes in clinical practice, counseling, and provide space for the autonomy of patients to exercise discretion in respect to patient's own capacities and capabilities.

Comprehending the guidance on medical treatment from the basic sources of Islam has throughout history culminated into different perceptions as present in classics of Islamic jurisprudence. These perceptions furthermore substantiate the trend on the subject which evades rigidity and encourages flexibility. The following section of the paper will explore the opinions of the jurists and contemporary juristic thought on the subject.

ISLAMIC MEDICAL JURISPRUDENCE: DIFFERENT PERCEPTIONS FROM IJTIHAD: The opinions on obligation to medical treatment in the works of Islamic jurisprudence are varied, held by their opponents due to their methodological preferences while making ijtihad. Muslim jurists are unanimous in upholding permissibility (ibaha) of medical treatment. Some jurists, while deliberating on the theological evidences, have formulated positions on medical treatment, relying considerably on the nature of diseases and medical conditions of patients; hence, different opinions are made on the issue, culminating in formulation of normative positions. However, a single normative position has tendency of reducing the whole issue of obligation to medication to a single guiding principle that may not fit in the holistic view based on various evidences from the 
Quran and the Sunnah on the subject. Ibn Taymiyyah (1263-1328 CE) has rightly appropriated it, as he states that the scholars have disputed on medication whether it is mubah (permissible), mustahab (recommended) or wajib (obligatory), when in fact, the correct view is that medication is of types, some of the types are muharram (prohibited) and makruh (disapproved) and some are mustahab, and wajib.

The jurists including some mystics have divided in two groups on the subject of medical treatment: opponents and proponents.

Opponents comprise of two groups. The first group is outrightly against medical treatment; some extremist sufi (mystics) belong to this group. ${ }^{37}$ Their justification follows from the popular concept of tawakkul (reliance upon Allah), believing that God ultimately holds power to heal and harm, and they drive on some Prophetic traditions which are understood, in an unholistic manner any literally, discouraging any obligation to medical treatment. However, the more reliable account that could be attributed to sufis is that permissibility of medication is not contrary to tawakkul and reliance upon Allah. ${ }^{38}$ On the other hand, there are juristic opinions that although treat medical treatment permissible, yet they prefer avoiding it. In Hanbili School of jurisprudence, avoiding medication is treated as the best option (afdal) to practice. ${ }^{39}$ Al-Muruzi also states that medication is permitted (ruksah) and avoiding it is the best option ${ }^{40}$; Imam Nawawi prefers the similar view. ${ }^{41}$ As a matter of fact, there are reports that some of the disciples of the Prophet (Sahabah) and the generation after the Sahabah (Tabieen) abstained from medication such as Abu Bakar, Abu Darda, Ubay Ibn Kaab and Abu Dhar; ${ }^{42}$ and their abstention was not disputed or "criticized by their contemporaries". ${ }^{43}$ The second group is of jurists who oppose medication in case the patient believes that it is medication alone -without Allah's permission-- that will heal him. Some Hanafi scholars hold this position. ${ }^{44}$

Proponents hold four positions: (1) mubah (permissible) (2) mustahab and mandub (recommended) (3) makruh (disapproved) and (4) wajib (obligatory). Permissibility (ibaha) of medication is held by the majority of scholars of Hanafiyah, Malikiyah, and Hanbaliah schools of Islamic jurisprudence. The overriding opinion (rajah) regarding medication is permission (jawaz) and consensus (ijma) of Sahabah and Tabeen is reported in favor of it. ${ }^{45}$ Among Hanafi scholars, Imam Kasani and Syafi'iyah School of jurisprudence treat medication mustahab and mandub. ${ }^{46}$ Some of the scholars of the first three centuries of Islam (salf) ${ }^{47}$ and Malikiyah School of jurisprudence treat medication makruh if the medication is yet to be discovered. Those who consider medication wajib (obligatory) comprise of two groups. The first group considers medication absolutely obligatory; they are some of the scholars of Hanbaliah school of jurisprudence. This view is supported by one of the opinions of Imam Ahmad ${ }^{48}$.The second group believes that medication is obligatory if a person knows that he will not live without it. This view is held by some scholars of Syafi'iyah and Hanbaliah schools of jurisprudence; ibn Taymiyyah holds the similar position. ${ }^{49}$

The traditional scholarship of Islamic jurisprudence as briefed above presents many perceptions of obligation to medical treatment, emerging basically from the original sources of Islam. The contemporary scholarship on the issue is clearer than the traditional discourse, especially in delineating classification of levels of obligation and their corresponding types of diseases with helpful conceptual content in understanding the nature of diseases under consideration.

CONTEMPORARY ISLAMIC APPROACH TO MEDICATION: The contemporary approaches to bioethics in Islamic writings are based on the aforementioned discourse in Islamic jurisprudence and reconsideration of the first two sources of Islam. The topics included in the traditional works of Islamic jurisprudence do not have separate chapters on bioethical matters. However, the subbranch of Islamic jurisprudence to which scholars contribute independently or institutions in an organized form called as fatwa has been meeting the challenges. In addition, independent 
scholars have written exclusive works on the subject. Juristic organizations and bodies have produced unanimous resolutions on the matters pertaining to bioethical issues. The professional organizations have also drafted codes. In terms of methods, a comprehensive study of these writings demonstrates that the contemporary writings on Islamic bioethics rely on five sources: (1) principles of Islamic jurisprudence (usool al- Fiqh) (2) higher intentions of Islamic law (maqasid alShariah) (3) maxims of Islamic law (al -qawaid al- fiqhiyah)). In addition, different from the traditional way of developing legal and moral positions, the writings on Islamic bioethics lay a great emphasis on (4) expert advice (clinicians) and (5) intentionality and capacities (of clinicians, patients, and guardians), allowing space for what has come to be known as "patient autonomy".

The jurisprudential discourse on medical treatment has culminated into some decisiveness in the contemporary time. Though different perceptions of medical treatment still matter to help in solving some issues that clinicians and patients face at times; however, the important issue is to decide when medical treatment becomes obligatory (wajib). Knowing this is important to many concerned people such as public policy experts, physicians, patients, guardians of the patients, insurance companies, employers, lawyers, etc. A very comprehensive statement worthy of consideration is the resolution of Islamic Fiqh Academy, al-Majma al-Figh al-Islami, on the medication that was made in its seventh session in Jeddah on $7-12,11,1412 \mathrm{~h}$. as follows: The medication is permissible because of its justification from the Quran, both statements and acts of the Prophet (Sunnah), and for the reason that it guards the self of a person, which is one of the basic objectives of the Shariah. The injunctions regarding medication differ according to patients. The medication becomes obligatory (wajib) in cases where not giving medication could cause death, disability or the loss of a limb, or where the sickness is bound to spread if not treated, as in contagious diseases. Medication becomes encouraged (mandub) in cases where not giving medication may weaken a person physically, and it is not as bad as the cases that are under preceding obligatory (wajib) type. It becomes optional or permissible (mubah) in cases which are not covered in the two preceding categories: wajib and mandub. It is discouraged or disliked (makruh) in cases where the treatment could lead to complications that are worse than the original disease that is considered to be cured. ${ }^{50}$ In these categories, it seems that decision making on medical treatment is solely based on the patient autonomy. However, in certain cases patient autonomy and consent is disregarded against greater good of public. Authorities have right to force medication in certain situations such as in case of contagious disease, or in case of giving of vaccines or inoculations. In an emergency, where lives are at stake, treatment does not depend on obtaining permission of patients. ${ }^{51}$ Furthermore, the medication of terminally ill patients should be in accordance to the expert advice of the doctors, the availability of medication in time and place and the circumstances of the patient. ${ }^{52}$

The abovementioned discourse on medication, which follows from the Quran and the Sunnah, shapes into guidelines and norms in the jurisprudential heritage of Islam and into resolutions of jurisprudential bodies in our contemporary time is still in need of further development to address the modern-day bioethical concepts, distinctions, and issues. One of such important issues is the distinction between ordinary and extraordinary means of medical treatment.

ORDINARY AND EXTRAORDINARY MEDICAL TREATMENT: CLASSIFICATION: Ordinary and extraordinary means of medical treatment distinction is important because of its usefulness in many medical issues. If, in some cases, medical treatment is obligatory in Islamic sense, as described above, then it needs to be demonstrated whether such obligation is absolute or conditional. Patients as individuals need to know it to make choices on medication. In addition, countries where access to medical treatment is right of a citizen, the public policy needs to be clear on what treatment is ordinary and what is extraordinary. In the corporate sector, the insurance companies also need to know which treatments they need to cover as ordinary and which they are not obliged to cover as extraordinary. In the similar manner, in a paternalistic model when right to refuse treatment may apply and when a surrogate's interest in approving or refusing medical treatment could be justified and considered in good faith, having a definite understanding of the issue becomes indispensable. Therefore, the question arises: is it possible to 
make a distinction between ordinary and extraordinary means of medical treatment on Islamic lines; and if so, what should be the basis for the distinction? In order to understand the issue, the below classification is followed:

1. Ordinary and Extraordinary distinction in regards to terminally ill patients

2. Ordinary and Extraordinary distinction in regards to non-terminally ill patients

ISLAMIC CONCEPT OF OBLIGATION (TAKLEEF): Islamic concept of obligation (takleef) is always qualified by some conditions and capacities that vary in respect to various duties and responsibilities. It is a concept which applies to all obligations. The central to the obligations (takleef) which comes with duty (ada) is that the person who is addressed with any obligation should be mukallaf: a mukallaf is a person who should have the capacity (ahliyyah) to carry out the duty. The concept of capacity (ahliyyah) is also understood as capability (istitaah). The classics of Islamic jurisprudence are clear on the subject of capacity (ahliyyah) with details regarding performing rituals, transactions, contracts and other various matters. However, on many ethical matters this concept has received insignificant treatment; obligation to medical treatment is one of such issues.

Therefore, construction of right concept of obligation (takleef) regarding medical treatment is in need of adequate formulations. The aforementioned classification of obligation to medical treatment as stated in the resolution of al-Majma al-Figh al-Islami is made in relevance to the nature of diseases. How a patient's own capacities and relevant circumstances and conditions affect the general rules brings the whole subject under a new scrutiny where general principles are subject to change on case by case basis by giving a patient due consideration as the subject who has influence on decision making. This line of thinking gives considerable weight to both the means of medical treatment and the patient in the process of deciding the obligation to medical treatment, generally, and, particularly, in determining extraordinary means of medical treatment. Methodologically, the abovementioned concepts are to be understood adequately for the purpose of formulating the distinction between ordinary and extraordinary means of medical treatment, and to do so in a sophisticated manner, it requires comprehensive study of the writings on the relevant issues including fatwas (edicts), codes, independent researches, organized resolutions on various medical issues that touch obligation to medication, patient consent and autonomy, nature of medication, and overall understanding of the issue from the evidences in the Quran and the Sunnah.

The study of relevant fatwas, cases, and statements that are available to me show that there are two factors which can lead to the formulation of the distinction between ordinary and extraordinary means of medical treatment. They are (1) patient capacity and (2) nature of medication. Along with these two factor, the determining factor is (3) expert advice. It is the experts who are right authority to judge patient capacity and nature of medication.

TERMINALLY ILL PATIENTS AND THE DISTINCTION: Regarding terminally ill patients, medical treatment can become extraordinary in certain instances; therefore, the patient would not be obliged to opt for medical treatment. The cases which come under this category, as the study of statements and fatwas on the relevant cases show, can be classified into two classifications: medication can be extraordinary, thus non-obligatory, because of (1) patient capacity and (2) nature of medication. In both these case expert advice taken from a group of physicians applies as the condition that would decide on the presence or absence of the capacity of the patient and the nature of the medication that may be under consideration.

PATIENT CAPACITY: Medication can become extraordinary, thus non-obligatory, if patients lack in certain capacities. Various statements of Muslim scholars on withholding, withdrawing, and suspending medical treatment from terminally ill patients include mention of certain capacities, and judging their absence or presence is determined by "expert advice". To illustrate this, for example, Mufti Ali Gomma's fatwa regarding euthanasia is helpful in discerning nature of extraordinary 
means of medical treatment. In light of his statement, using life sustaining medical equipment with patients with no hope to recover and without any progress made on restoring their health becomes extraordinary, precisely when the patients are "clinically dead"; however, he qualifies such a decision with expert advice taken from physicians. ${ }^{53}$ Muzammil Siddiqi of the Fiqh Council of North America supports stopping medication when a patient is in terminal condition with no hope of recovery and switching off the life support machine with due consultation and care when expert advice from medical experts determine so. ${ }^{54}$ Islamic Medical Association of North America (IMANA) supports discontinuing life support except nutrition and hydration when a patient is in a "vegetative state". ${ }^{55}$ Council of Islamic Jurisprudence (al-Majma al-Fiqh al-Islami) issued a resolution on discontinuing, on advice of specialist and experienced doctors, life support system when patient's brain functions cease completely even if some of the patient's organs like the heart are kept functional by artificial means. ${ }^{56}$ On the issue of resuscitation, Standing Committee for Academic Research and Issuing Fatwas (Fatwa al-Lajnah al-Daimah) endorsed "Do Not Resuscitate" (DNR) in several cases including when the patient's condition is not fit for resuscitation; when patient's sickness is chronic and untreatable, and death is inevitable; if the patient is incapacitated, or is in a persistent vegetative state and chronically ill, or in the case of cancer in its advanced stages, or chronic heart and lung disease, with repeated stoppages of the heart and lungs; if there is any indication in the patient of brain injury that cannot be treated; and if reviving the heart and lungs is of no benefit and not appropriate because of a certain situation. Most of these cases are conditioned with "expert advice", three trustworthy specialist doctors. ${ }^{57}$

NATURE OF MEDICATION: Some means of medical treatment can become extraordinary because of the nature of medical treatment itself: by examining the quality, usefulness, and effectiveness of the means of medical treatment. In this case, categorizing medical treatment as extraordinary depends primarily on the expert advice taken from a group of physicians or medical committees. For example, The Islamic Code of Medical Ethics, in its Article Sixty-Two allows "the termination of a treatment when its continuation is confirmed, by the medical committee concerned, to be useless, and this includes artificial respirators, in as much as allowed by existing laws and regulations" and "declining to begin a treatment that is confirmed to be useless". ${ }^{58}$ Sheikh Yusuf Al-Qaradawi holds that a physician can suspend useless medical treatment for the sake of the patient's comfort and the relief of his family. ${ }^{59}$ Sheikh Muhammed Salih Al-Munajid holds the view that if there is no certainty that treatment will be of benefit, and indeed it is likely to cause suffering to the patient, then there is nothing at all wrong with not giving the treatment. ${ }^{60}$ Furthermore, Islamic Code of Medical Ethics states that "If it is scientifically certain that life cannot be restored then it is futile to diligently keep the patient in a vegetative state by heroic measures or to preserve the patient by deep freezing or other artificial methods". ${ }^{6}$

NON-TERMINALLY ILL PATIENTS AND THE DISTINCTION: In regards to non- terminally ill patients, the concept of ordinary and extraordinary means of medical treatment has not been given any adequate treatment in the current bioethics; however, it is possible to formulate the concept of extraordinary means of medical treatment on Islamic lines. Medical treatments which are known useless, their harm is more than the diseases in question, or are deceptive in their effects, and which while being free from these defects are not possible because of the financial incapacity of the patients are extraordinary. Some of these types of treatment are even treated not only extraordinary but also prohibited by statements made by some Islamic scholars in fatwa literature. There are three types of means of medical treatment, as they seem to me, which deserve to be categorized as extraordinary in respect to non-terminally ill patients. They are: (1) treatment that is known to be useless and futile; (2) treatment that may endanger the life or cause more harm than what it removes; and (3) treatment is useful, but the patient is unable to bear the cost.

USELESS AND FUTILE TREATMENT: The means of medical treatment that are known to be useless and futile are extraordinary. Therefore, because of the nature of the medication, such medication would not be obligatory for a Muslim patient in case the obligation to medical treatment falls within the obligatory (wajib) category; this decision has to be based on the advice of expert 
physicians, as the research shows that expert advice has decisive importance in almost all cases in which treatment is withheld or discontinued. This position is further supported by the legal maxim: al yaqin la yuzal bil shakk, certainty is not dispelled by doubt. If there is certainty that the medical treatment will not cure the patient, doubting otherwise will not turn that medical treatment into ordinary.

LIFE ENDANGERING AND HARMFUL TREATMENT: Those means of medication are extraordinary if they cause danger to life or cause more harm than they could possibly remove. The legal maxims state: no injury or countering injury (la darar wa-la dirar); "harm must be eliminated but not by means of another harm" (ad-dararu yuzalu wa lakin la bi-darar); "harm is not eliminated by another harm" (ad-dararu la yuzalu bid-darar); and "harm is not eliminated by the similar harm" (Ad-dararu la yuzal bi mithlihi). However, "a greater harm is eliminated by means of a lesser harm" (ad-dararu alashadd yuzal bid-darar al-akhaff).

UNBEARABLE, OVER- COSTLY MEDICATION: The very important component of any obligation in Islam is the capacity or takleef of a patient. This capacity could be broken down into many subcomponents relevant to various religious obligations. Regarding sickness and disease, if a patient is not in position to pay the expenses of medication, in that case the patient does not have any obligation to medication. The Prophetic tradition states that "...if I forbid you to do something, then keep away from it. And if I order you to do something, then do of it as much as you can." ${ }^{62}$ To help such patients in paying the expenses for medication, governments, charity organizations, society, and individuals do play some role. And it would be encouraged on Islamic lines. Shariah compliant insurance system called takaful can also be a solution. In Islam, all these ways are permissible besides Islam encourages donating (sadqah) to those who are needy. Even obligatory form of charity or alms-tax (zakah) could be spent on such cases. For example, Shaykh ibn Uthymin in Majmu al -Fataawa while answering the question, "Is it permissible to give zakah to those who are suffering from kidney failure?" responds, "...A person's need for medical treatment is a real need, so if we find someone who needs medical treatment but does not have enough money to pay for treatment, there is nothing wrong with giving zakah to him, because the aim of zakah is to meet people's needs." 63

CONCLUSION: The researcher attempted to show the importance of medical treatment from the primary sources of Islam: the Quran and the Sunnah, and, furthermore, how this issue is debated by Muslim jurists in the classics of Islamic jurisprudence. Connecting the traditional discourse to the latest development in Islamic jurisprudence, the researcher showed that medical treatment becomes obligatory (wajib) if its abandonment leads to the fatality of the life or an organ or its inability or the disease transmits to others such as communicable diseases. Deriving on this concept of obligation, the researcher discussed the distinction of ordinary and extraordinary means of medical treatment. The researcher showed that the distinction can be made in two ways regarding terminally ill patients and non-terminally ill patients. The factors that lead to the distinction between ordinary and extraordinary treatment are: (1) patient capacity (2) expert advice, and (3) nature of medication. Regarding terminally ill patients, medical treatment can become extraordinary if it is (1) extraordinary because of patient capacity and (2) extraordinary because of nature of medication. In both these case the condition applies and that is expert advice taken from a group of physicians. In regards to non- terminally ill patients, the three types of extraordinary means of medical treatment are very prominent: (1) treatment that is known to be useless and futile, (2) treatment that may endanger the life or cause more harm than what it removes, and (3) treatment is useful, but the patient is unable to bear the cost. 


\section{REFERENCES:}

1. The Quran, 2:2.

2. The Quran, 4:59.

3. Kamali MH. Maqasid al-Shariah Made Simple Herndon: The International Institute of Islamic Thought; 2009.

4. The Quran, 4:79.

5. The Quran, 6: 17.

6. The Quran, 26:80.

7. See The Quran, 38: 41-44.

8. The Quran, 10: 57.

9. The Quran, 17:82.

10. The Quran, $41: 44$.

11. Al-Bukhari. Sahih al-Bukhari. Beirut: Dar Ibn Kathir; 2002/1423h. Hadith No:5737.

12. The Quran, 16: 69.

13. See The Quran, 4: 42 and 5:6.

14. See The Quran, 2:185.

15. See The Quran, 2:196.

16. Ibn-Qayyim. Zad al-Maad fi Hadyi Khair al-lbad. Beirut: Dar Al-Kotob Al-Ilmiyah.

17. The Quran, 17: 33.

18. The Quran, 4: 93.

19. The Quran, 4:29.

20. The Quran, 5:2.

21. At-Tirmidhi. Sunan at-Tirmidhi. Beirut: Dar Ihya al-Turath al-Arabi. Hadith No: 2038.

22. Al-Bukhari. Sahih al-Bukhari. Beirut: Dar Ibn Kathir; 2002/1423h. Hadith No:5678 .

23. Abu Dawud. Sunan Abi Daawud Mohideen M, editor: Darul Fikir. Hadith No: 3874.

24. Ibn Hambal. Musnad Imam Ahmad ibn Hambal. Cairo: Muasasah Qurtubah. Hadith No:3578 .

25. Ibn-Majah. Sunan Ibn Majah. Al-Qazuwaini MbYAA, editor. Beirut: Darul Fikir. . Hadith No: 3436. 
26. Al-Bukhari. Sahih al-Bukhari. Beirut: Dar Ibn Kathir; 2002/1423h. Hadith No:5692 .

27. Al-Bukhari. Sahih al-Bukhari. Beirut: Dar Ibn Kathir; 2002/1423h. Hadith No:5687 and 5688.

28. Al-Bukhari. Sahih al-Bukhari. Beirut: Dar Ibn Kathir; 2002/1423h. Hadith No:5417 .

29. Al-Bukhari. Sahih al-Bukhari. Beirut: Dar Ibn Kathir; 2002/1423h. Hadith No:5728 .

30. At-Tirmidhi. Sunan at-Tirmidhi. Beirut: Dar Ihya al-Turath al-Arabi. Hadith No: 2055.

31. Muslim. Sahih Muslim. Beirut: Dar Ihya' al-Turath al-'Arabi. Hadith No: 320 and Al-Bukhari. Sahih al-Bukhari. Beirut: Dar Ibn Kathir; 2002/1423h. Hadith No:5752 .

32. Al-Bukhari. Sahih al-Bukhari. Beirut: Dar Ibn Kathir; 2002/1423h. Hadith No:5742 .

33. At-Tirmidhi. Sunan at-Tirmidhi. Beirut: Dar Ihya al-Turath al-Arabi. Hadith No: 2065 .

34 . Al-Bukhari. Sahih al-Bukhari. Beirut: Dar Ibn Kathir; 2002/1423h. Hadith No: 4458.

35. Al-Bukhari. Sahih al-Bukhari. Beirut: Dar Ibn Kathir; 2002/1423h. Hadith No:5652 .

36. Ibn-Taymiyyah TA. Majmu Fatawa Ibn Taymiyyah al-Kubra. Cairo: Dar ar-Rahmah.

37. Al-Nawawi. Sahih Muslim bi Sharh al-Nawawi. Beirut: Dar al-Fikr and al-Jawzi. Talbis Iblis. Beirut: Darul Fikir 2001.

38. Al-Nafrawi. Al-Fawakih al-Dawani fi Sharh Risalat Ibn Abi Zayd al-Qayrawani. Beirut: Darul Fikir; $1415 \mathrm{~h}$.

39. Al-Bahuti. Kashshaf al-qina an mitan al-iqtina. Beirut: Darul Fikir 1402h.

40. Al-Hanbali. Ghidha' al-albab li-sharh manzumat al-adab. Egypt1993.

41. Ibn-Taymiyyah TA. Majmu Fatawa Ibn Taymiyyah al-Kubra. Cairo: Dar ar-Rahmah.

42. Al-Makki AT. Qut al-qulub fi mu'amalat al-mahbub wa wasf tariq al-murid ila maqam al-tawhid. Cairo: al-Isfahani and Al-Ghazali. Ihya Ulum Al Din. Beirut: Dar al-Kutob al-Ilmiyyah.

43. Ibn-Taymiyyah TA. Majmu Fatawa Ibn Taymiyyah al-Kubra. Cairo: Dar ar-Rahmah.

44. Al-Zaliee F. Tibyaan Haqiq Sharah Kanz al-daqiq. Beirut: Darul Kutub Al-Islamiyah; 1313h.

45. Ibn-Hazm AMA. Maratib al-ijma fi al-ibadat wa-al-muamalat wa-al-itiqadat. Beirut: Darul-kutub al-IImiyyah.

46. Kasani ABAa-D. Badai al-sanai fi tartip al syarai. Beirut: Darul Kutub Arabi; 1982 and AlNawawi AZ. al-Majmu sharh al-Muhadhdhab. Beirut: Darul Fikir 1997.

47. Al-Kalbi IJ. Qawanin al-Fiqhiyah. Ibn-Nujaym. Bahr-ur-Raik Sharhu Kanz al-Daqaiq. Beirut: Darul Marifah.

48. Ibn-Taymiyyah TA. Majmu Fatawa Ibn Taymiyyah al-Kubra. Cairo: Dar ar-Rahmah. 
49. Ibn-Taymiyyah TA. Majmu Fatawa Ibn Taymiyyah al-Kubra. Cairo: Dar ar-Rahmah.

50. Resolution of the Islamic Figh Academy On Medicine. Organization of Islamic Conference; [cited 201320 April 2013]; Available from: http://www.saaid.net/tabeeb/69.htm.

51. Resolution of the Islamic Fiqh Academy On Medicine. Organization of Islamic Conference; [cited 201320 April 2013]; Available from: http://www.saaid.net/tabeeb/69.htm.

52. Organization of Islamic Conference. Majallat Majma al-Fiqh al-islami, Vol. 6, 3/1791.

53. Goma A. Ethics of Euthanasia. [cited 201112 March]; Available from: http://infad.usim.edu.my.

54. Siddiqi M. Is euthanasia allowed in Islam? [cited 201113 March]; Available from: http://www.islamonline.net.

55. IMANA Ethics Committee. Islamic Medical Ethics: The IMANA Perspective. Journal of Islamic Medical Association 2005; July 37.

56. Organisation of Islamic Conference. Majallat Majma al-Fiqh al-islami 2(3).

57. Ruling on removing life-support for a cancer patient. islamqa; [cited 201320 April]; Available from: http://islamqa.info/en/ref/105328.

58. The International Islamic Code for Medical and Health Ethics The Islamic Organization for Medical Sciences; [updated 1981]; Medical Behavior and Physician Rights and Duties Social Issues [Available from: http://www.islamctr.org/codepart1chapter5.asp.

59. Al-Qaradawi Y. Islam's Stance on Euthanasia. 2005 [cited 20115 May]; Available from: http://www.islamonline.net/servlet/Satellite?pagename=IslamOnline-English-

Ask_Scholar/FatwaE/FatwaE\&cid=1119503544774.

60. Al-Munajjid SMS. Ruling on medical treatment. [Fatwa] [updated 12 March 2011]; Available from: http://www.islamqa.com/en/ref/2438.

61.Islamic Code for Medical and Health Ethics. The Islamic Organization for Medical Sciences; 1981 [cited 201320 April]. Available from: www.emro.who.int/docs/EM_RC52_7_en.pdf.

62. Al-Bukhari. Sahih al-Bukhari. Beirut: Dar Ibn Kathir; 2002/1423h. Hadith No:7288 .

63. Can zakaah be given to one who suffers from kidney failure? : islamqa; [cited 201320 April]; Available from: http://islamqa.info/en/ref/105328. 